\title{
Redescription of holotype Dermestes impressus Pic, 1898 (Coleoptera: Dermestidae: Dermestinae)
}

\section{Переописание голотипа Dermestes impressus Pic, 1898 (Coleoptera: Dermestidae: Dermestinae)}

\section{J. Háva \\ И. Гава}

Daugavpils University, Institute of Life Sciences and Technology, Department of Biosystematics, Vienobas Str. 13, Daugavpils LV - 5401 Latvia. E-mail: jh.dermestidae@volny.cz. Private Entomological Laboratory and Collection, Rýznerova 37, CZ - 252 62 Únětice u Prahy, Praha-západ, Czech Republic.

Даугавпилсский университет, Институт естественных наук и технологий, отдел биосистематики, Даугавпилс, Латвия. Частная энтомологическая лаборатория и коллекция, Прага, Чехия.

Key words: taxonomy, redescription, illustrations, Coleoptera, Dermestidae, Dermestes impressus, Algeria.

Ключевые слова: таксономия, паереописание, иллюстрации, Coleoptera, Dermestidae, Dermestes impressus, Алжир.

Abstract. The holotype of species Dermestes (Dermestes) impressus Pic, 1898 is shortly redescribed and firstly illustrated.

Резюме. В статье даются переописание и иллюстрации голотипа Dermestes (Dermestes) impressus Pic, 1898.

\section{Introduction}

During the determination in year 2017 of some Dermestidae (Coleoptera) deposited in the Museum National d' Histoire Naturelle, Paris, France, collectio generalis and collectio Maurice Pic. I have discovered the type of species belonging to the genus Dermestes. This type is studied in this article.

\section{Material and methods}

The nomenclature and zoogeography follow Háva [2015]. Individual labels are indicated by a single slash (/). All photos by author were taken by a Nikon Coolpix 990 digital camera through an MBS 10 binocular stereo microscope.
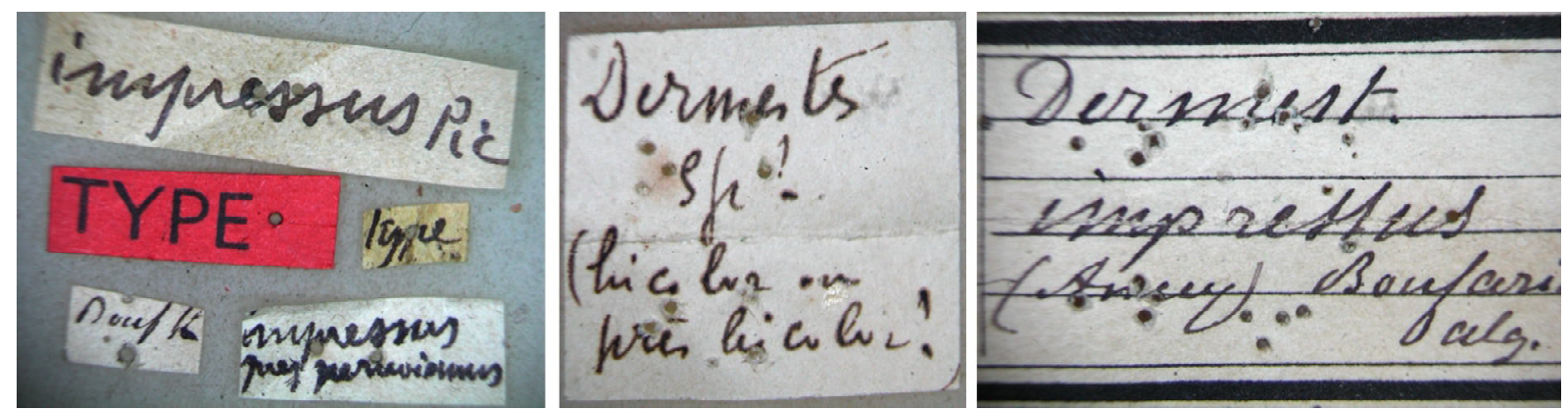

Dermestes Linnaeus, 1758

Dermestes (Dermestes) Linnaeus, 1758

Dermestes bicolor species group

Dermestes (Dermestes) bicolor

ssp. impressus Pic, 1898

Figs $1-10$.

Dermestes impressus Pic, 1898: 2.

Dermestes bicolor ssp. impressus: Háva, 2003: 23; Háva 2015: 6 .

Type material. Holotype (unsexed) torso: «Bouf Va» «impresses pres peruvianus» / «impressus Pic» / «TYPE» / «Type» / «Dermest. impressus (Ancey) Boufarik Alg.» «Dermestes sp. bicolor ou pres bicolor». Holotype deposited in Muséum National d'Histoire Naturelle, Paris, France.

Distribution. Subspecies known from Algeria, Egypt, Tunisia and Morocco.

Remarks. The species described by Pic [1898] according to holotype specimen. Háva [2003] according to original description and Kalík's dravings stated the species as subspecies of Dermestes bicolor. Study of type destroyed specimen (destroyed by Anthrenus species) this status confirmed.
Dermestes impressus: Mroczkowski, 1968: 2.

Fig. 1. Original labels of Dermestes bicolor ssp. impressus Pic, 1898.

\footnotetext{
Рис. 1. Этикетки голотипа Dermestes bicolor ssp. impressus Pic, 1898.
} 
Dermestes impressus. - Assex ditroit et allongé, peu brillamt. entièrement roux,

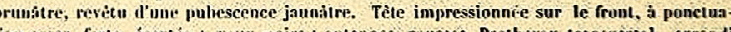
tion asse: forte. ceartio ; yeux noirs; antennes rousses. Prothorax transversal, arrond

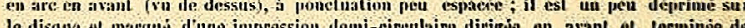
chaque cötí dans une autre impression profonde. Ëlytres assez parallieles, finement granuleux, avec des sortes de sillons à peine indiguis. Dessous du corps d'un brum moustatre. comme te tessus, pubesicent de jaune.

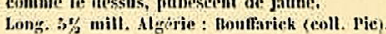
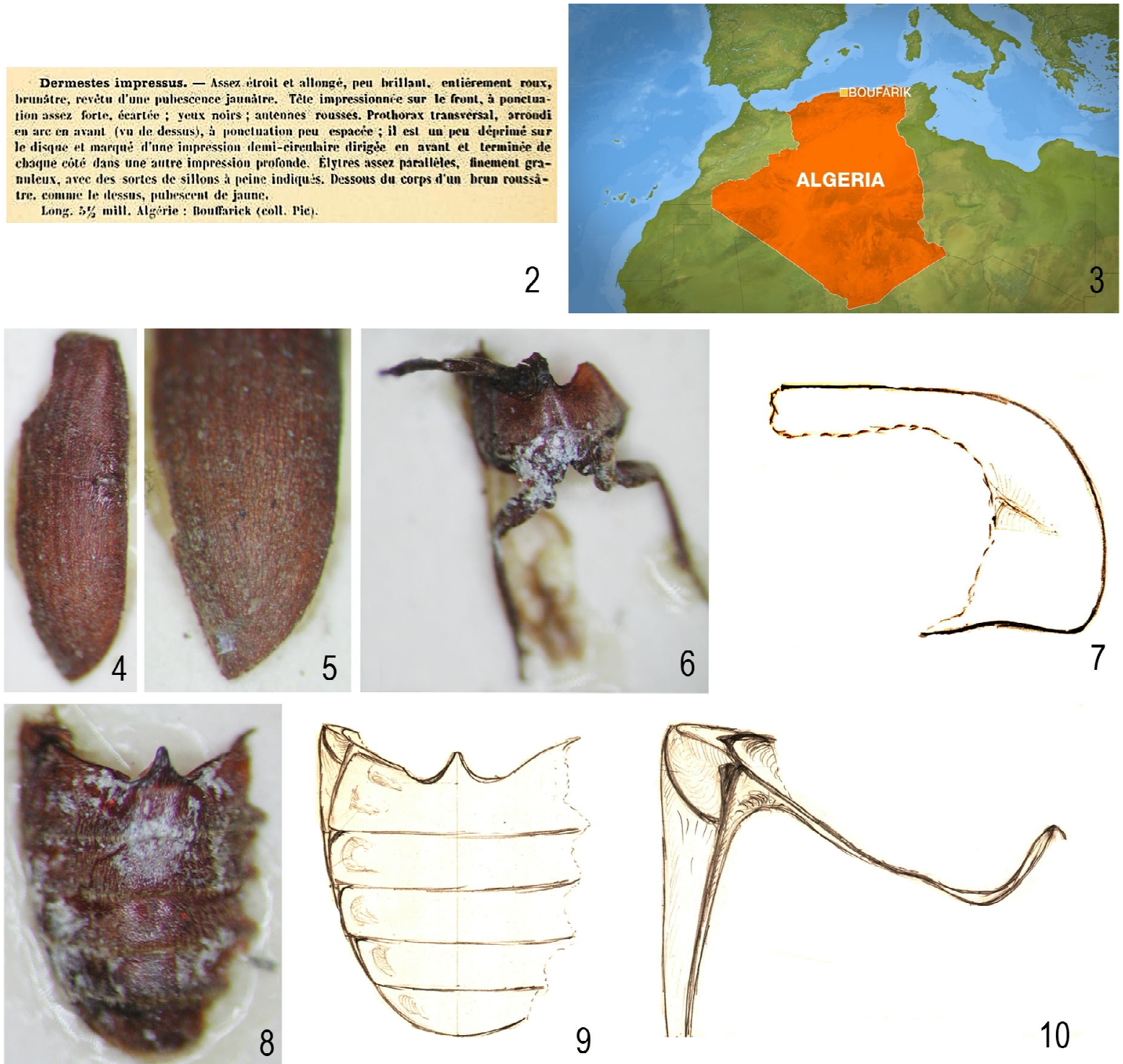

Figs 2-10. Dermestes bicolor ssp. impressus. 2 - original description, 3 - map of type locality. 4 - elytron, 5 - apical part of elytron, $6-$ prosternum and legs, $7-$ destroyed part of pronotum, 8, $9-$ abdominal ventrites, $10-$ lateral depressions on first abdominal ventrite.

Pис. 2-10. Dermestes bicolor ssp. impressus. 2 - оригинальное описание, 3 - типовое местообитание, 4 - надкрылье, 5 - вершинная часть надкрылья, 6 - переднегрудь и ноги, 7 - переднеспинка, 8, 9 - вентриты, 10 - катеральное вдавление на первом вентрите.

\section{Acknowledgements}

I am very indebted to Azadeh Taghavian (National d'Histoire Naturelle, Paris, France) for helping me to study the material in Museum Paris, to my very good friend Jan Hrdlièka (Prague, Czech Republic) for collegial help on our shared trip to Paris and to †Vladimír Kalík for dravings.

\section{References}

Háva J. 2003. World Catalogue of the Dermestidae (Coleoptera) // Studie a Zprávy Oblastního Muzea Prahavıchod. Suppl.1. 196 p.

Háva J. 2015. World Catalogue of Insects. Vol.13. Dermestidae (Coleoptera). Leiden/Boston: Brill, xxvi +419 p.

Mroczkowski M. 1968. Distribution of the Dermestidae (Coleoptera) of the world with a catalogue of all known species // Annales Zoologici. Vol.26. P.15-191.

Pic M. 1898. Variétés et Nouvelles Espéces de Coléoptéres // Miscellanea. 